\title{
OFFSHORE COMPANIES' PARTICIPATION IN STRATEGIC STATE PROJECTS AND THEIR IMPACT ON STATE BUDGET REVENUE
}

\author{
Vaidas GAIDELYS* \\ Kaunas University of Technology, Gedimino g. 50, LT- 44309, Kaunas, Lithuania \\ *E-mail: vaidas.gaidelys@ktu.lt
}

\begin{abstract}
Purpose - to assess possible consequences of the employment of offshore companies in strategic state projects.

Research methodology - empirical research statistical data analysis.
\end{abstract}

This publication introduces scientific research on the case of employment of offshore companies in strategic state projects and assesses its possible damage to state budget revenue.

Findings - offshore financial centres specialise in serving particular economic sectors.

Research limitations - although developed countries suffer the most significant tax revenue losses, they promote the establishment of offshore centres. Countries do not learn from their mistakes, especially in terms of tax evasion through offshore companies.

Practical implications - by employing offshore companies in its strategic projects, Lithuania supports the double standards and the principle that what the state is allowed to do, private business is not.

By taking advantage of offshore companies, corruption offences can be financed.

Originality/Value - this article introduces the new empirical research on employment of offshore companies in strategic state projects.

Keywords: offshore companies, strategic projects, corruption, state budget tax revenue.

JEL Classification: C12, D53, F31, O31.

Conference topic: Contemporary Financial Management.

\section{Introduction}

One of the functions of a state is to set business rules, mandatory to all market participants. Compliance with these rules is controlled by a state by employing all measures available.

Businesses employ offshore companies for two purposes: tax reduction and confidentiality which allows hiding the real aims of transactions or the origin of capital. In accordance with the real purposes of their establishment, offshore companies can even serve as a cover for criminal activities, such as money laundering, corruption offense financing and/or plundering of budget funds, under the cover of legal transactions when these transactions are carried out through offshore companies with the aim to artificially inflate prices of goods or services so that the surplus could be embezzled (Bergström, Helgesson, \& Mörth, 2011).

The large interests that state governors and businesses have in offshore companies were confirmed by the Panama Papers scandal which revealed the existence of 214000 offshore companies in more than 200 states and their territories (Internal Revenue Service Estimates, 2016).

The conduct of such businesses helps to cover the processes of money laundering. Although establishment and management of an offshore company is not a crime in case this company pays taxes and is not involved in criminal offences, offshore companies are often exploited for concealment of the origins of illegally obtained money (Crivelli, Mooij, \& Keen, 2015).

The PANA committee, established in the middle of 2016, is researching whether the EU regulations on the prevention of money laundering and tax evasion are properly implemented. The research was started when nearly two years ago the Panama Papers scandal arose. Then, after leaking the correspondence of the Panama legal service company Mossack Fonseca, the information on over 213 thousand foreign companies and their owners, including 12 
current and former state governors, nearly 200 politicians and a large number of celebrities, was disclosed. During the scandal, a total of 2.6 terabytes of the confidential information, i.e. 11.5 million documents, was publically announced. This amount of data was higher than that leaked over the scandals taken together. Thus far, it has been the biggest leak of the information on money laundering and tax evasion. Flawed tax practices were also revealed by the Paradise Papers scandal which arose in the autumn of 2017 (Table 1) (Zucman, 2015).

The PANA committee notes that some EU member states have recently introduced citizenship programs for non-EU residents (e.g., golden visas or investment programs) that grant the rights to citizenship in exchange to financial investment, but a person's income sources and business customers are not checked (EU Council Directive, 2015).

The data announced by the Europol indicate that the Panama Papers are linked to only 0.6 per cent of the total number of annually recorded money laundering cases. The PANA committee warns that it is just the tip of an iceberg since the company Mossack Fonseca, which occupies only 5-10 per cent of the secret overseas.

\section{Global situation}

The statistics show that 1.5-2.8 trillion US dollars, i.e. between 2 and 5 per cent of the global GDP, are lost annually due to money laundering practices, while the amounts of the money laundered through offshore territories vary from 1 to 21 trillion US dollars (van Koningsveld, 2015).

Table 1. Offshore wealth and tax evasion 2014 (source: Zucman, 2015)

\begin{tabular}{|l|c|c|c|}
\hline \multicolumn{1}{|c|}{ Region } & $\begin{array}{c}\text { Offshore Wealth in Billion } \\
\text { USD }\end{array}$ & $\begin{array}{c}\text { Share in Financial Wealth } \\
\text { held Offshore }\end{array}$ & $\begin{array}{c}\text { Tax Revenue loss in billion } \\
\text { USD }\end{array}$ \\
\hline Europe & 2,600 & $10 \%$ & 78 \\
\hline United States of America & 1,200 & $4 \%$ & 35 \\
\hline Asia & 1,300 & $4 \%$ & 34 \\
\hline Latin America & 700 & $22 \%$ & 14 \\
\hline Africa & 500 & $30 \%$ & 6 \\
\hline Canada & 300 & $9 \%$ & 1 \\
\hline Russia & 200 & $52 \%$ & 0 \\
\hline Gulf Countries & 800 & $57 \%$ & 190 \\
\hline Total & 7,600 & $8 \%$ & \\
\hline
\end{tabular}

The table above shows that Europe is the region that bears the most substantial tax revenue loss, amounting to 78 US dollars; 10 per cent of the total European financial assets, or 2,600 billion US dollars, are held in offshore accounts. The USA in 2014 lost 34 billion US dollars of its tax revenue;

4 per cent of the country's total financial assets, or 1200 billion US dollars, are held in offshore accounts (Raczkowski, 2015). The USA is an attractive region for offshore activities since it has some offshore zones, for instance, in the State of Delaware, where formal offshore companies are granted tax exemptions in case they earn their revenues outside the USA, or, as it is stipulated by the law, "outside a zone or a state if an offshore zone is established not all over a state". By employing offshore zones, the US economy is able to attract extra funds and at the same time control the information which is related to the activities of offshore companies (Biggins, 2013).

The statistics on the situation in other regions show that nearly 52 per cent of the total Russian financial assets, or 200 billion US dollars, are held in offshore territories, and in 2014 Russia lost about 1 billion US dollars of its tax revenue; African offshore wealth amounts to 30 per cent of the region's total financial assets or 500 billion US dollars, and in 2014 Africa lost 14 US dollars of its tax revenue; the offshore wealth in Latin America amounts to 22 per cent of the region's total financial assets or 700 billion US dollars, and in 2014 Latin America lost 21 billion US dollars of its tax revenue; offshore accounts hold 9 per cent of Canadian total financial assets or 300 billion US dollars, and in the year under consideration the country lost 6 billion US dollars of its tax revenue; the offshore wealth amounts to 4 per cent of the Asian total financial assets or 1300 billion US dollars, and in 2014 Asia lost nearly 34 billion US dollars of its tax revenue; finally, the offshore wealth in the Persian Gulf Countries amounts to 57 of the region's total financial assets, or 800 billion US dollars, although in 2014 the region was not found to bear any loss in its tax revenue. The total global offshore wealth amounts to 8 per cent of the total global financial assets or 7600 billion US dollars, and nearly 190 billion US dollars of tax revenue is lost annually (Busuoic, 2006).

Although the activities of offshore companies are restricted by issuing new regulations, the financial interests of stakeholders are larger than the efforts to stop them (Figure 1) (Government of the Isle of Man, 2016). 


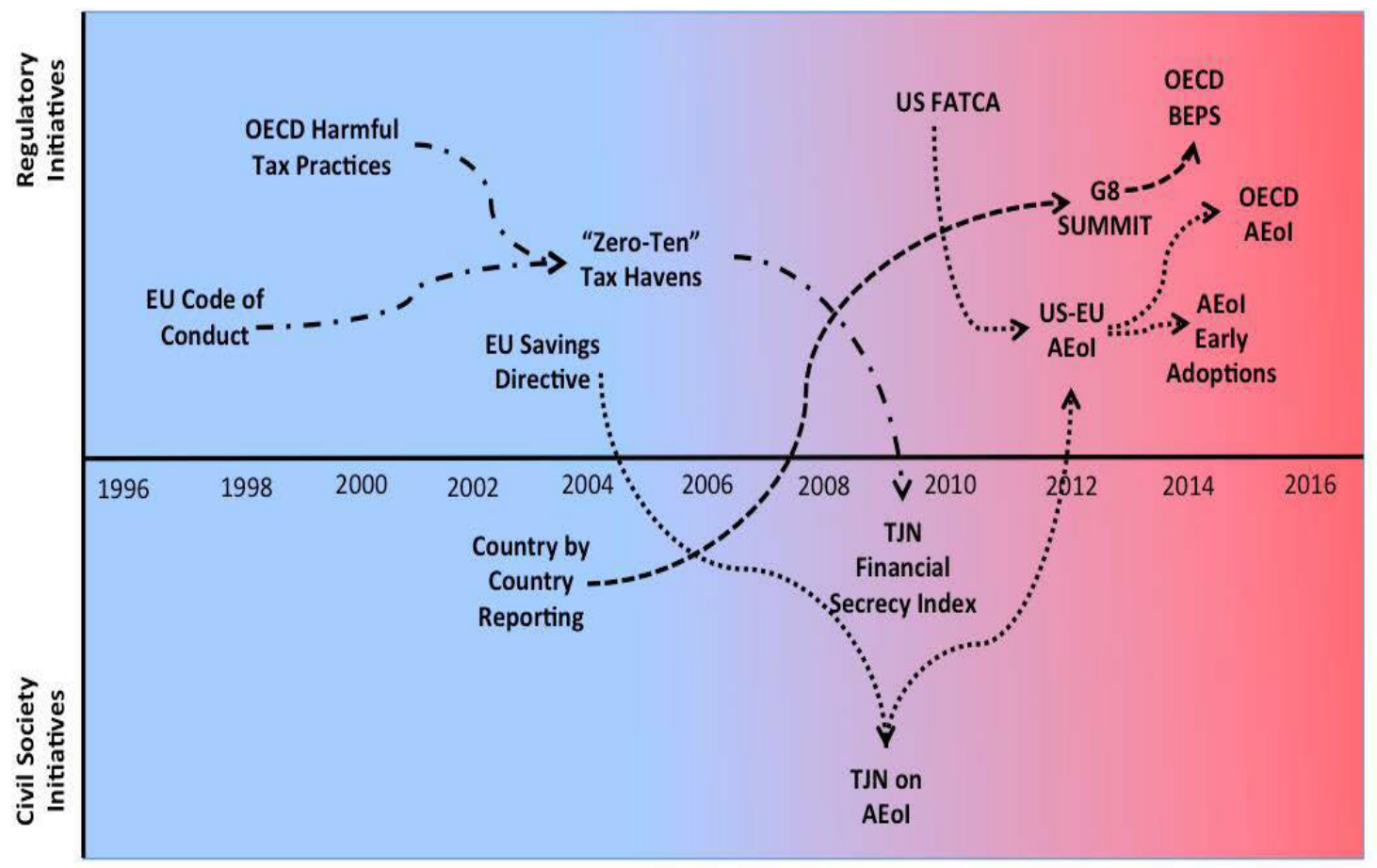

Figure 1. The evolution of tax evasion regulation 1996-2016 (source: COFFERS, 2016)

\section{The impact of the Panama Papers on EU member states}

After the leak of the Panama Papers, many EU member states suffered the losses in their reputation. The most significant losses were suffered by Great Britain, Luxembourg, Ireland, Cyprus, Spain, Estonia, Malta and Latvia. Undoubtedly, offshore companies in Great Britain were popular due to the existence of the offshore zones, such as the British Virgin Islands and the Isle of Man, established by the country itself. Luxembourg was interesting for its financial centres and minimum tax levels. Before accession to the EU, both Malta and Cyprus used to be offshore territories, and Cyprus is still extremely popular with Russian entrepreneurs who want to move their capitals from Russia. Moreover, Cyprus applies minimal tax tariffs allowed in the EU. Estonia also applies tax exemptions for those who invest in the country; in addition, it borders on Russia and Finland, which makes it attractive to entrepreneurs from the East. Although the Panama Papers reveal only a small part of the global offshore activities, they indicate particular tendencies and lead to particular conclusions (see Table 2-3).

Table 2. Offshore activities of EU-28 Member States in the Panama Papers (ICIJ, 2016).

\begin{tabular}{|c|c|c|}
\hline County/Area Offshore & Offshore Entities & Officers \\
\hline Austria & 76 & 121 \\
\hline Belgium & 61 & 363 \\
\hline Bulgaria & 50 & 117 \\
\hline Croatia & 20 & 38 \\
\hline Cyprus & 6374 & 3678 \\
\hline Czech Republic & 173 & 272 \\
\hline Denmark & 14 & 65 \\
\hline Estonia & 881 & 108 \\
\hline Finland & 66 & 60 \\
\hline France & 304 & 1005 \\
\hline Germany & 197 & 504 \\
\hline Greece & 223 & 400 \\
\hline Hungary & 90 & 186 \\
\hline Iceland & 15 & 213 \\
\hline reland & 1936 & 261 \\
\hline Italy & 347 & 1196 \\
\hline
\end{tabular}


Table 3. Offshore activities of selected countries in the Panama Papers (ICIJ, 2016)

\begin{tabular}{|l|c|c|}
\hline Panama & 18122 & 5357 \\
\hline Switzerland & 38077 & 4595 \\
\hline United States & 6254 & 7325 \\
\hline Hong Kong & 51295 & 25982 \\
\hline British Virgin Islands & 69092 & 15211 \\
\hline Jersey & 14562 & 7100 \\
\hline Monaco & 3168 & 1398 \\
\hline United Arab Emirates & 7772 & 3397 \\
\hline Liechtenstein & 2070 & 1147 \\
\hline
\end{tabular}

Another topical issue is the exploitation of offshore financial centres for illegal activities. Although some authors state that offshore financial centres in principle refer to small scattered islands, today more and more of them are discussing what impact the world's largest countries have on these small islands and the offshore financial centres located there (Sharman, 2006).

Application of the newest research methods for evaluation of the global corporate assets helped to detect 71 million components, linked to offshore financial centres (Javier, Fichtner, Eelke, \& Frank, 2017). In 2015, the above-mentioned authors used the data from the ORBIS database comprising 200 million public and private enterprises worldwide (Orbis database, 2017). This helped to identify the offshore financial centres in which foreign companies hold their capitals. 23 offshore financial centres were found to attract substantial shares of foreign capital. It was also found that foreign capital reaches the financial centres through the Netherlands, the UK, Ireland, Switzerland and Singapore. The authors note that the UK serves as an intermediary between European countries and Luxembourg, Bermuda, Jersey, British Virgin Islands and Cayman Islands (Knobel \& Meinzer, 2016a, 2016b).

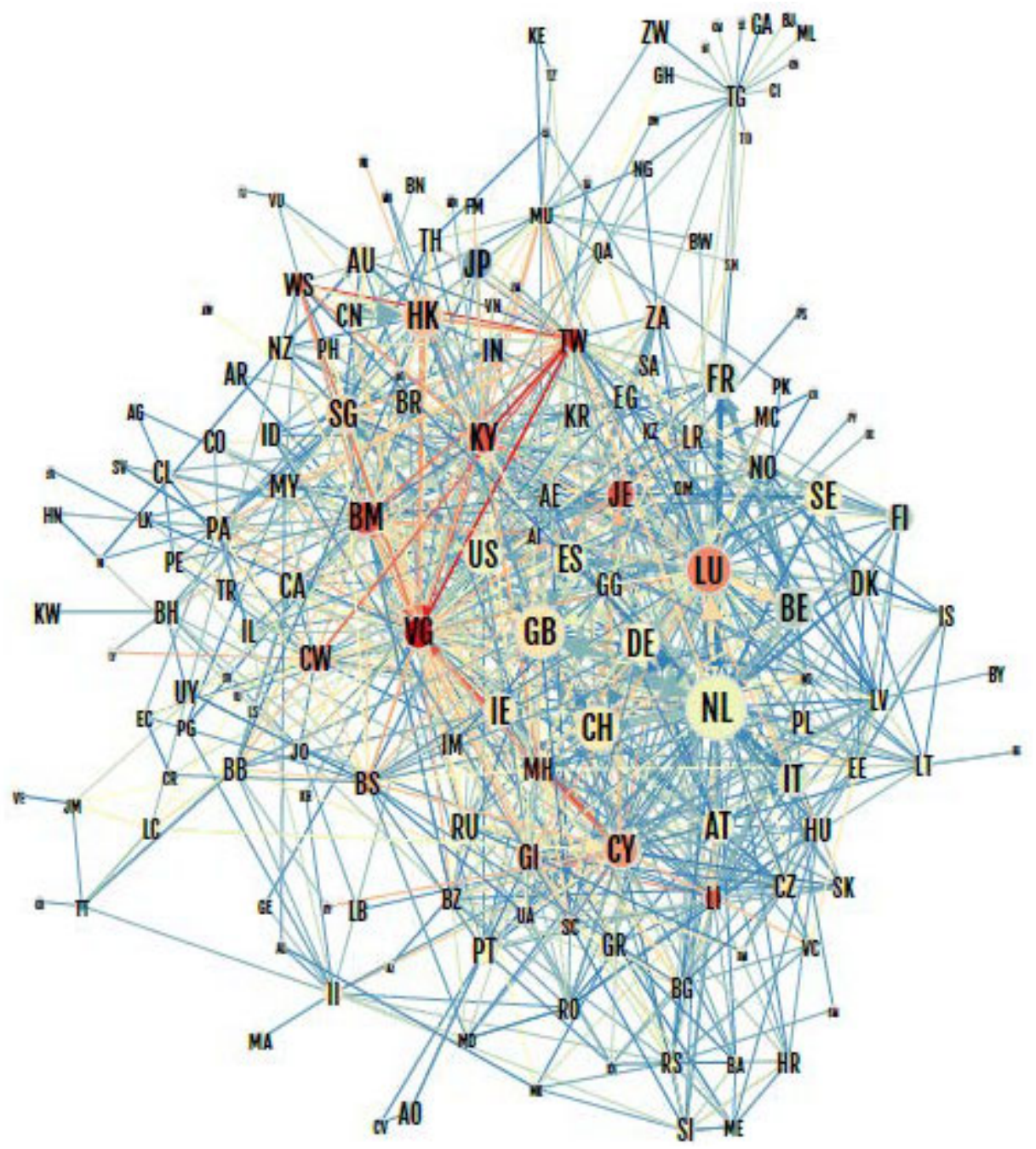

Figure 2. Centres in the Global Corporate Ownership Network (Javier et al., 2017). 
The Netherlands mediate between European countries and Luxembourg, Curacao, Cyprus and Bermuda. Luxembourg and Hong Kong companies invest directly in European countries and China without employment of the offshore financial centres. The authors also detected intensification of the investment moving from low-tax countries, such as Bermuda, British Virgin Islands and the Cayman Islands, to the companies established in other offshore territories (CASE \& CPB, 2013).

Hence, the results of the recent studies contradict to the previous findings, which proposed that the main offshore financial centres were established in the Caribbean Islands, and show that a significant number of offshore financial centres operate in developed countries (Savona \& Riccardi, 2017). Figure 2 depicts the network of the value flow between/among particular countries. The different colours in the figure indicate the relative importance of the link: red is used for the values that stay (sink), while yellow marks the through flow. The position of a country in the network is set so that well-connected countries are close in space. This is reflected by European countries placed close to the Netherlands (NL) and Luxembourg (LU), while Asian countries are placed close to Hong Kong (HK) and other sink-OFCs, and the United Kingdom (GB) acts as an integrator between Europe and Asia. Figure 2 shows a connected inter-sink-OFC network, with the British territories triplet British Virgin Islands (VG), Bermuda (BM), and Cayman Islands (KY) at the centre (Figure 2) (Javier et al., 2017).

Table 5 gives an overview of the countries identified as sink Offshore Centres, where global values are parked, and of Conduit Offshore Centres, where global values flow through (see Column 1). Column 2 lists the Oxfam tax havens, Column 3 indicates the tax havens according to the Financial Secrecy Index of the Tax Justice Network, and Column 4 provides the EU 2015 world tax havens blacklist, while Column 5 presents the IMF 2000 list of cooperative versus non-cooperative countries. Here 1 stands for "non-cooperative", 2 stands for "below international standards", and 3 stands for "generally cooperative" countries. Column 6 ranks the countries according to the IMF 2008 Assessment Program for Offshore Centres (COFFERS, 2016) (Table 4).

Table 4. Opinion of international organizations (2016)

\begin{tabular}{|c|c|c|c|}
\hline & PANA Committee Study & Oxfam & FSI 2015 \\
\hline & Sink-OFCs & & \\
\hline Luxembourg & 1 & 7 & 6 \\
\hline Hong Kong & 2 & 9 & 2 \\
\hline British Virgin Island & 3 & 15 & 21 \\
\hline Bermuda & 4 & 1 & 34 \\
\hline Cyprus & 5 & 10 & 35 \\
\hline Cayman Island & 6 & 2 & 5 \\
\hline Jersey & 7 & 12 & 16 \\
\hline Taiwan & 8 & & \\
\hline Curacao & 9 & 8 & 70 \\
\hline Malta & 10 & & 27 \\
\hline Mauritius & 11 & 14 & 23 \\
\hline Liechtenstein & 12 & & 36 \\
\hline Bahamas & 13 & 11 & 25 \\
\hline Samoa & 14 & & 51 \\
\hline Gibraltar & 15 & & 55 \\
\hline Marshall Islands & 16 & & 14 \\
\hline Liberia & 17 & & 33 \\
\hline Seychelles & 18 & & 72 \\
\hline Belize & 19 & & 60 \\
\hline Guyana & 20 & & \\
\hline St Vincent and Grenadines & 21 & & 64 \\
\hline Nauru & 22 & & \\
\hline \multirow[t]{2}{*}{ Anguilla } & 23 & & 63 \\
\hline & Conduit-OFCs & & \\
\hline Netherlands & 1 & 3 & 41 \\
\hline United Kingdom & 2 & & 15 \\
\hline Switzerland & 3 & 4 & 1 \\
\hline Singapore & 4 & 5 & 4 \\
\hline Ireland & 5 & 6 & 37 \\
\hline Belgium & Small & & 38 \\
\hline
\end{tabular}


End of Table 4

\begin{tabular}{|c|c|c|c|}
\hline & PANA Committee Study & Oxfam & FSI 2015 \\
\hline Guernsey & Small & & 17 \\
\hline \multirow[t]{2}{*}{ Panama } & Small & & 13 \\
\hline & Non-OFCs & & \\
\hline Barbados & & 13 & 22 \\
\hline Antigua and Barbuda & & & 65 \\
\hline Grenada & & & 82 \\
\hline Montserrat & & & 92 \\
\hline St. Kitts and Nevis & & & 69 \\
\hline Turks and Caicos Islands & & & 68 \\
\hline \multirow[t]{2}{*}{ US Virgin Islands } & & & 50 \\
\hline & EU 2015 & IMF 2000 & IMF2008 \\
\hline Luxembourg & 1 & 7 & 6 \\
\hline Hong Kong & 2 & 9 & 2 \\
\hline British Virgin Island & 3 & 15 & 21 \\
\hline Bermuda & 4 & 1 & 34 \\
\hline Cyprus & 5 & 10 & 35 \\
\hline Cayman Island & 6 & 2 & 5 \\
\hline Jersey & 7 & 12 & 16 \\
\hline Taiwan & 8 & & \\
\hline Curacao & 9 & 8 & 70 \\
\hline Malta & 10 & & 27 \\
\hline Mauritius & 11 & 14 & 23 \\
\hline Liechtenstein & 12 & & 36 \\
\hline Bahamas & 13 & 11 & 25 \\
\hline Samoa & 14 & & 51 \\
\hline Gibraltar & 15 & & 55 \\
\hline Marshall Islands & 16 & & 14 \\
\hline Liberia & 17 & & 33 \\
\hline Seychelles & 18 & & 72 \\
\hline Belize & 19 & & 60 \\
\hline Guyana & 20 & & \\
\hline St Vincent and Grenadines & 21 & & 64 \\
\hline Nauru & 22 & & \\
\hline \multirow[t]{2}{*}{ Anguilla } & 23 & & 63 \\
\hline & Conduit-OFCs & & \\
\hline Netherlands & 1 & 3 & 41 \\
\hline United Kingdom & 2 & & 15 \\
\hline Switzerland & 3 & 4 & 1 \\
\hline Singapore & 4 & 5 & 4 \\
\hline Ireland & 5 & 6 & 37 \\
\hline Belgium & Small & & 38 \\
\hline Guernsey & Small & & 17 \\
\hline \multirow[t]{2}{*}{ Panama } & Small & & 13 \\
\hline & Non-OFCs & & \\
\hline Barbados & & 13 & 22 \\
\hline Antigua and Barbuda & & & 65 \\
\hline Grenada & & & 82 \\
\hline Montserrat & & & 92 \\
\hline St. Kitts and Nevis & & & 69 \\
\hline Turks and Caicos Islands & & & 68 \\
\hline US Virgin Islands & & & 50 \\
\hline
\end{tabular}


The study helped to identify the offshore financial centres from an economic point of view. Ireland together with the UK specialises in the establishment of main offices. In the value chain, 90 per cent of the value generated by Luxembourg as by a financial flow channel ends in an unknown offshore financial centre. Similar tendencies are observed in Hong Kong, Singapore and Ireland (Miller, Rena, Rosen, \& Jackson, 2016). 70 per cent of Switzerland's financial value ends in the sector of mining and quarrying in Jersey. Electronics and computer manufacturers mostly use Hong Kong services, holding companies rely on such channels as the Netherlands and Luxembourg, while the other financial sectors enjoy the benefits provided by Ireland (Zdanowicz, 2016). Finally, the Netherlands is active in the sector of business support services concentrated in Luxembourg. In all of the above-mentioned cases, the clear specialisation of different economic sectors in offshore financial centres can be observed. The analysis of previous research proposes the following conclusions (Table 5) (Cobham, Jansky, \& Meinzer, 2015):

Table 5. Major findings and estimates on Offshore Companies in Koningsveld 2015 (PANA Committee, 2017)

\begin{tabular}{|c|c|}
\hline What is estimated & Volume \\
\hline Number of Worldwide pure OFCs & $1,583,702$ \\
\hline Number of world mixed OFCs & 561,978 \\
\hline Foreign Legal Persons registered in NL & 40,044 \\
\hline OFCs registered in NL & 3,438 \\
\hline Managed wealth worldwide & 8,900 billion $\$$ \\
\hline Managed offshore wealth of Dutch people & 143,586 million $\$$ \\
\hline Offshore managed wealth & $5-7,000$ billion $\$$ \\
\hline Money flow through Dutch SPEs & 8,610 billion $€$ \\
\hline Directly acquired real by OFCs in NL & 1,620 million $€$ \\
\hline Directly financed real by OFCs in NL & 23.6 billion $€$ \\
\hline Unusual transactions by OFCs in NL & 1.1 billion $€$ \\
\hline Offshore loans in NL & 1.3 billion $€$ \\
\hline Evidence found for OFC abuse in \% cases & $54 \%-58 \%$ \\
\hline No. of OFCs are abused in (drug) criminal cases & 57 \\
\hline Illegal transactions (corruption, worldwide) & 56.4 billion $\$$ \\
\hline Sources & Time \\
\hline Trade registers, INCSR, Company formation survey & 2013 \\
\hline Trade registers, INCSR, Company formation survey & 2013 \\
\hline Dutch trade register & 2013 \\
\hline Dutch Tax Authority & 2006 \\
\hline Global Wealth Report & 2013 \\
\hline Global Wealth Report & 2010 \\
\hline OECD & 2007 \\
\hline DNB & 2012 \\
\hline Housing Register Cadastre & 2013 \\
\hline Housing Register Cadastre & 2013 \\
\hline FIU & $2010-2013$ \\
\hline Tax authorities/FIOD & 1997 \\
\hline FIOD/National Investigation agency & $2010-2013$ \\
\hline 29 FIOD cases & 2004-2016 \\
\hline The Puppet Masters, 150 cases & Till 2011 \\
\hline
\end{tabular}

\section{Lithuania's participation in the activities of offshore companies}

At the national level, Lithuania joined the countries that employ offshore companies for the implementation of their strategic plans. On one hand, when Biržai pipeline was still being exploited (in 2003), the main product and crude oil transporters were offshore companies, mostly owned by private oil traders. On December 3, 2014, the exploitation of the liquefied natural gas terminal, which was referred to as a priority having a strategic impact on Lithuanian energy security, was started. It should be noted that the terminal itself was acquired through a specially-established offshore company, and gas was bought from another offshore company, established in London (WODC Project, 2017). This proposes that by implementing its national-level strategic projects through offshore companies, Lithuania promotes offshoring in business and supports the double standards for the offshoring companies employed by the state and the 
ones operating in the private sector. Tolerance of the double standards and categorisation of offshore companies as "transparent" and "non-transparent", as declared by the former Minister of Energy, makes an impression that what the state is allowed to do, private business is not.

Also, some reasonable doubts concerning the possible cases of corruption while implementing the abovementioned strategic project can be raised considering the fact that the offshore companies involved in the project are directly linked to aggressive tax planning (or even tax evasion) and confidentiality of the origin of capital. In this case, it is difficult to control the money flowing from the Lithuanian national budget (i.e. taxpayers' money) to the accounts of the offshore companies. What is more, having in mind the aggressive tax planning tools used by Lithuania as a state, it is difficult to justify Lithuanian tax policy and agree with the proposition that it effectively fights tax evasion.

Tax administrators can hardly get the data on money movement in offshore accounts and can hardly identify the real owners of the accounts in offshore companies (Unger, Broek, Ferwerda, \& Deleanu, 2014).

The companies, operating in the area of international business, are free to decide what business model to select, but their selection serves as a background to assess the level of social responsibility in these companies. Excluding the aspects of social justice and international business, this research addressed the social responsibility of Lithuania as a state renting liquefied natural gas terminal through offshore companies. When ignoring the problems with offshore companies, revealed during the Panama Papers scandal, the state is still implementing its strategic project through the same offshore companies, the private business receives the message that employment of offshore companies for international operation is, in fact, promoted.

Just after 2001, Enron, one of the largest US energy enterprises, went bankrupt, which was a result of data forgery. In November 2001, this enterprise suffered a 618 million USD loss. In 1990, many obscure accounting entries (which can be referred to as fraud) were detected in Enron and its accounting partner Arthur Andersen (later this firm collapsed and had to pay the damages amounting to 40 million USD). Some offshore centres (Grand Cayman and Turks and Caicos), incorporating over 800 offshore companies, were involved in the Enron's collapse scheme, and the damage worth over 7.1 billion USD was done (Seabrooke \& Wigan, 2017). This way, the offshore schemes led to the largest bankruptcy in U.S. history at that time.

With reference to historical sources, such global schemes involve the largest global corporations and most famous business advisory companies. If earlier Lithuanian special investigation service institutions were able to fight corruption and financial offences inside the country (the cases were usually closed without receiving a reply from abroad), over the last 10 years the country has been able to enter global business markets where operation of offshore companies is not uncommon (Van der Veen \& Ferwerda, 2016). The existence of this practice is confirmed by the information on the activities of Alstom's subdivision in Sweden (which paid potentially illegal rewards to Lithuanian energy sector officials) announced by the Serious Fraud Office in the UK (Fischer \& Lotz, 2014).

Offshore companies are clearly damaging the revenues of national budgets, this way deepening social injustice. So what is the state's position with regard to offshore companies? Can a business, operating in an international market, benefit from offshore companies without persecution? Those who treat offshore companies as legal are partly right because offshore companies indeed comply with legal regulations of a country or territory where they are registered, and it would be naive to consider the laws in force, for instance, the laws of the State of Delaware in the USA or the Isle of Man in the UK, to be questionable. Nevertheless, it remains unclear where the money that settles in the accounts of offshore companies is transferred from and where this money later flows to (Unger, Broek, Joras, \& Deleanu, 2017).

Offshore companies are commonly employed for reduction of tax burden (mainly profit taxes) and concealment of the origin of capital. What is more, they can actively participate in money laundering operations and corruption offences. As tax evasion distorts the real effects that offshore companies have on business, offshore activities can lead to unreasonable and harmful taxation and capital outflows. Inaccurate information, in its turn, can distort the Laffer curve when assessing the actual impact of taxes on state budget revenues (Van den Broek, 2015).

What could individual countries do to discourage international business from using offshore services? Tax reduction is one of the possible solutions. That is exactly what the Irish government did. In order to attract investment by multinational corporations, the Irish government granted tax privileges to Apple corporation, i.e. it reduced profit tax from 12.5 to 1 per cent in 2007, and to 0.0005 per cent in 2014. Google was also offered some special tax incentives. However, despite their positive effects, such practices may serve as a dangerous precedent involving countries into tax competition, which contradicts the presumption that taxes serve as a measure to implement social justice. Hence, what advantages provided by offshore companies are actually gained, depends on the objectives of offshore business founders.

\section{Conclusions}

- Offshore financial centres specialise in serving particular economic sectors;

- Although developed countries suffer most significant tax revenue losses, they promote the establishment of offshore centres; 
- Countries do not learn from their mistakes, especially in terms of tax evasion through offshore companies;

- By employing offshore companies in its strategic projects, Lithuania supports the double standards and the principle that what the state is allowed to do, private business is not;

- By taking advantage of offshore companies, corruption offences can be financed.

From the Panama Papers, it also follows that a Dutch legal firm is involved by establishing dubious constructions where offshore companies are involved.

\section{References}

Bergström, M., Svedberg Helgesson, K., \& Mörth, U. (2011). A new role for profit actors? The case of anti money laundering and risk management. JCMS: Journal of Common Market Studies, 49(5), 1043-1064.

Biggins, J. (2013). Dirty complexity: money laundering through derivatives. In B. Unger \& D. van der Linde, Research handbook on money laundering (pp. 321). Edward Elgar Publishing. https://doi.org/10.4337/9780857934000.00035

Busuoic, M. (2006). Money laundering techniques (Chapter 5). In B. Unger \& D. van der Linde, Black finance - the economics of money laundering. Policy Department A: Economic and Scientific Policy European Parliament.

CASE \& CPB. (2013). Study to quantify and analyse the VAT Gap in the EU-27 Member States Final Report. Warsaw: Center for Social and Economic Research - Netherlands Bureau for Economic Policy Analysis - European Commission DG TAXUD. Retrieved from https://ec.europa.eu/taxation_customs/sites/taxation/files/docs/body/vat-gap.pdf

Cobham, A., Jansky, P., \& Meinzer, M. (2015). The financial secrecy index: shedding new light on the geography of secrecy (pp. 281-303). Center for Global Development.

COFFERS. (2016). Combating fiscal fraud and empowering regulators. Ongoing EU Horizon 2020 Project, under leadership of B. Unger 2016-2019.

Crivelli, E., de Mooij, R., \& Keen M. (2015). Base erosion, profit shifting and developing countries. IMF Working Paper 15/118. 2015. https://doi.org/10.5089/9781513563831.001

EU Council Directive 2015/849 of the European Parliament and of the Council of 20 May 2015 on the prevention of the use of the financial system for the purposes of money laundering or terrorist financing.

Fischer, M., \& Lotz, S. (2014). Is soft paternalism ethically legitimate? - the relevance of psychological processes for the assessment of nudge-based policies. Cologne Graduate School Working Paper Series.

Government of the Isle of Man. (2016). Treasury customs and excise division, trade-based money laundering, notice 1000 MAN. Retrieved from https://www.gov.im/media/1348726/notice-1000-man-trade-based-money-laundering-29-sep-16.pdf

ICIJ. (2016). Offshore Leaks database. Retrieved from https://offshoreleaks.icij.org/

Internal Revenue Service Estimates. (2016). Tax evasion costs the US gov't. 458 billion. Retrieved from www.fortune.com

Javier, B., Fichtner, J., Eelke, H., \& Frank, T. (2017). Identifying sink and conduit offshore financial centers in the global corporate ownership network. Working paper of the University of Amsterdam.

Knobel, A., \& Meinzer, M. (2016a). Drilling down to the real owners, Part I. Tax Justice Network Report, FATF.

Knobel, A., \& Meinzer, M. (2016b). Drilling down to the real owners, Part II. Tax Justice Network Report, FATF.

Miller, R. S., Rosen, L. W., \& Jackson, J. K. (2016). Trade-based money laundering: overview and policy issues. In Congressional Research Service. CRS Report prepared for members and Committees of Congress.

Orbis database. (2017). Bureau van Dijk. Retrieved from https://orbis.bvdinfo.com/

PANA Committee. (2017). Offshore activities and money laundering: recent findings and challenges. Policy Department A: Economic and Scientific Policy European Parliament.

Raczkowski, K. (2015). Measuring the tax gap in the European Economy. Journal of Economics and Management, 21(3).

Savona, E. U., \& Riccardi, M. (2017) (Eds.). Assessing the risk of money laundering in Europe: Final Report of Project IARM. Università Cattolica del Sacro Cuore. Milano. Retrieved from www.transcrime.it/iarm

Seabrooke, L., \& Wigan, D. (2017). The governance of global wealth chains. Review of International Political Economy. https://doi.org/10.1080/09692290.2016.1268189

Sharman, J. C. (2006). Havens in a storm: the struggle for global tax regulation. Cornell University Press.

Unger, B., Broek, M., Joras, F., \& Deleanu I. (2014). The economic and legal effectiveness of anti-money laundering policy. Edward Elgar, Cheltenham, UK. https://doi.org/10.4337/9781785369551

Unger, B., Getzner, M., \& Linde, D. (Eds.). (2017). Public or private goods? Redefining the Res Publica. Edward Elgar.

Van den Broek, M. (2015). Preventing money laundering: A legal study on the effectiveness of supervision in the European Union $(\mathrm{PhD})$. Utrecht University.

Van der Veen, H., \& Ferwerda, J. (2016). National risk assessment. A Pilote Study. WODC.

Van Koningsveld, T. J. (2015). De offshore wereld ontmaskerd: Een studie naar aard en omvang van het misbruik maken van offshore vennootschappen door Nederlandse (rechts) personen (The offshore world disguised). Uitgeverij Kerckebosch bv.

WikiLeaks. (2010). Wake Island offshore labour contracts. Retrieved from https://search.wikileaks.org/?q=offshore

WODC Project. (2017). Aard en omvang van criminele investeringen. Wetenschappelijk Documentatiecentrum, the Netherlands, project leader Unger.

Zdanowicz, J. S. (2016). Trade-based tax evasion and money laundering - 2003 to 2014. Fiscal Intelligence Unit.

Zucman, G. (2015). Tax evasion and the "Swiss cheese" regulation. Retrieved from http://www.piketty.pse.ens.fr/files/Rousille2015.pdf 